\title{
Robert V. Daniels, 1926-2010
}

Robert V. ("Bill") Daniels, professor emeritus of history at the University of Vermont (UVM), died in Burlington on 28 March 2010. He was 84 years old. A distinguished scholar of Russian and Soviet political history, Daniels contributed a remarkable 21 books and more than 150 articles that enriched our understanding of Russia. For more than half a century, Daniels was the dean of Soviet studies in northern New England.

A pioneer in the study of the Russian revolution and the genesis of the Soviet political system, Daniels was among an early cohort of American scholars to challenge Cold War shibboleths about the Soviet Union, and his work quickly received both national and international attention. His first book, The Conscience of the Revolution: Communist Opposition in Russia (1960), was translated into German, Italian, and Japanese editions. Other important works from his early career include The Stalin Revolution: Fulfilment or Betrayal of Communism (1965), which went through four editions, and a seminal history of the Russian revolution, Red October: The Bolshevik Revolution of 1917 (1967). His Documentary History of Communism in Russia (1960), which went through many editions, was adopted for Soviet history courses in universities across the United States.

In the second part of his career, Daniels turned his attention away from the revolution to the study of Soviet politics. This work includes The Dynamics of Soviet Politics (1976), Russia: The Roots of Confrontation (1985), and Is Russia Reformable? (1988). Daniels's putative "retirement" in 1988 gave him more time to think and write. He published seven books focusing on contemporary Russian as well as Soviet politics, among them The End of the Communist Revolution (1993), Russia's Transformation: Snapshots of a Crumbling System (1998), and The Rise and Fall of Communism in Russia (2007).

Daniels also published outside the field of Russian studies, including The Year of the Heroic Guerilla: World Revolution and Counterrevolution in 1968 (1989) and a work of which he as a linguist was especially proud, Fodor's Europe Talking: A Guide to Nineteen Languages (1975). His oeuvre is characterized by his breadth of knowledge, superb research, acute insights, and elegant prose. His fair-minded and scrupulous approach to Soviet history at the height of the Cold War is especially noteworthy.

This body of work received support from the Guggenheim Foundation, the International Research and Exchanges Board (IREX), the Kennan Institute, and the Rockefeller Foundation and enabled Daniels to travel regularly to the USSR, as a fellow at Moscow State University and the USSR Academy of Sciences. He was active in the American Historical Association as well as in the American Association for the Advancement of Slavic Studies (AAASS), where he served as vice president (1991) and president (1992). He was a member of numerous editorial boards; of particular importance to him were the Journal of Trotsky Studies and the Journal of Contemporary History. He contributed regularly to Dissent and the New Leader. In 2001, he received the AAASS's award for Distinguished Contributions to Slavic Studies.

Robert Vincent Daniels, known as Bill, was born in Boston on 4 January 1926, but his roots were in Vermont. His grandfather was a professor of mathematics at UVM, and his father, an army officer, was an alumnus. Because Daniels moved from military base to military base during his childhood, he especially enjoyed spending his summers in Vermont with his grandparents at their stately historic home. When he came to teach at UVM, he moved into this house, and remained there until his death. In 1943, he graduated from St. Albans School in Washington, D.C., and entered Harvard as an economics major. The following year he joined the U.S. Navy, and after a stint in the V-12 program, he served as paymaster on the USS Albany, a heavy cruiser.

In 1946, Daniels received his bachelor's degree from Harvard, magna cum laude, and then continued on at Harvard earning both the MA and PhD degrees in Russian history. After he received his PhD in 1951, he worked in research and teaching positions at the Massachusetts Institute of Technology, Bennington College, Indiana University, and Co- 
lumbia University before joining the history department at UVM in 1956, where he worked until his retirement in 1988 .

Daniels achieved his extraordinary record of scholarly accomplishment-an authentic demonstration of "Bolshevik tempo"-while a full-time teacher and administrator at an institution with a heavy teaching load and without a research library or doctoral program. As a teacher, he was admired for his challenging courses and truly impressive knowledge of just about everything. As an administrator, he was the founding director of the Area and International Studies Program at UVM, 1962-65, and a co-founder of the Center for Research on Vermont. He chaired the history department, 1964-69, and directed the Experimental Program of the College of Arts and Sciences, 1969-71. He edited a history of UVM for its bicentennial celebrations in 1991. The university honored him with a University Scholar designation in 1982 and an honorary LLD in 1994. In 2004, the Area and International Studies Program created the Robert V. Daniels Award for Outstanding Contributions to the Field of International Studies.

Daniels was also an active citizen of the state of Vermont. From 1973 to 1982, he served in the Vermont Legislature as State Senator from Chittenden County. One of the founders of the Vermont-Karelia sister state project, he served on its advisory board and was also a trustee of the Vermont Historical Society.

This recital of his professional accomplishments gives insight into Bill Daniels as a professor and scholar, but what about Daniels as a person? He had a fertile mind and catholic interests, and his erudition, which ranged far beyond the Russian studies field, was truly amazing. (When a friend shared a Norwegian poem with him, Daniels immediately recognized the language not as Norwegian but as Nynorsk, an artificial poetic language invented in the nineteenth century.) So strong was his enthusiasm for history and politics that he never really aged. He loved wit and humor. He was constantly thinking new thoughts, investigating new fields, teaching anyone who would listen, and reading the staggering amounts of stuff piled on every flat surface in his office and study at home. His opinions prompted real reflection and commanded special respect. One of the least prepossessing scholar-intellectuals that one could hope to meet, Daniels was a genuine, supportive, and friendly colleague.

The last year of Daniels's life was a difficult one. At the beginning of 2009 , he suffered a major stroke that kept him in a nursing facility for months. His mind remained as sharp as ever, and his ability to maintain his good spirits was inspiring. Foremost on his mind were his latest writing projects (although he became addicted to the Sudoku puzzles that a colleague brought him).

Daniels is survived by his wife of 64 years, the former Alice Wendell, and by his four children and four grandchildren. Bill's keen intellect, generous sense of humor, and positive attitude will be missed by everyone who knew him

Denise J. Young Blood University of Vermont September 2010

\section{Moshe Lewin, 1921-2010}

Born in Wilno, Poland, on 6 November 1921, Moshe (Misha) Lewin was the product of a unique cosmopolitan culture in which Jews, Poles, Lithuanians, and Russians lived uneasily together. Life in a place of such intense political activity forced one to choose one's movement literally as an act of self-defense. For young Misha the choice was Hashomer Hatsair, a Zionist socialist youth movement that proposed a non-nationalist, binational state for Arabs and Jews in Palestine. When his home city, then the capital of Soviet Lithuania, was invaded by the Germans, Lewin escaped eastward. He never saw his family again. Both his Russian-speaking mother and his father, a butcher whom Misha described as a real "Hercules," were murdered by the Nazis. Misha eventually reached the Urals where he worked on farms, in factories, and in a mine before joining the Soviet Army and moving westward back toward Poland. As an officer, he witnessed the victory parade on Red Square in May 1945. 